\title{
STRATEGI PENGEMBANGAN KURIKULUM PONDOK PESANTREN MODERN ISLAM ASSALAM SURAKARTA
}

\section{CURRICULUM DEVELOPMENT STRATEGY OF ISLAMIC MODERN BOARDING SCHOOL ASSALAM SURAKARTA}

\author{
Yettty Faridatul Ulfah ${ }^{1}$, Novianni Anggraini ${ }^{2}$, Fithriyah Nurul Hidayati ${ }^{3}$ \\ ${ }^{I} I M M$ (Institut Islam Mamba'ul Ulum Surakarta), ${ }^{2}$ FAB IAIN Surakarta, ${ }^{3}$ FAB IAIN Surakarta, \\ Email:zetyfu@gmail.com \\ noviannianggraini1983@gmail.com \\ Fithriyahnh04@gmail.com
}

\begin{abstract}
Curriculum development is part of improving the quality of national education that must be done comprehensively. The purpose of this study is to describe the curriculum development in PPMI Assalam Surakarta. The research method used in this study is qualitative descriptive method, with research approach in the form of case study. The results showed that there are two systems combined in the pattern of education in PPMI Assalaam with the Salafiyah education system with the modern education system in teaching and learning activities adhere to the school system in general. Four of the components are objectives, curriculum content, strategy and evaluation. Component specifications of objectives related to the four core competencies of graduates that must be mastered or achieved by the students of PPMI Assalaam, namely spiritual, intellectual, moral, and skill core competencies. Ppmi Assalam Surakarta curriculum content component is organized in three forms of activities, namely curricular activities, co-curricular activities and extracurricular activities. The components of the learning strategy are used to enable students to actively participate in learning democratically and enjoyably. The evaluation component contains continuous and thorough assessments.
\end{abstract}

Keywords: curriculum development, islamic boarding school, Assalam Surakarta

\begin{abstract}
Abstrak
Pengembangan kurikulum merupakan bagian dari peningkatan mutu pendidikan nasional yang harus dilakukan secara komprehensif. Tujuan dari penelitian ini untuk mendeskripsikan pengembangan kurikulum yang terdapat di PPMI Assalam Surakarta. Metode penelitian yang digunakan dalam penelitian ini adalah metode deskriptif kualitatif, dengan pendekatan penelitian berupa studi kasus. Hasil penelitian menunjukkan adanya dua sistem yang dipadukan dalam pola pendidikan di PPMI Assalaam dengan sistem pendidikan Salafiyah dengan sistem pendidikan modern dalam kegiatan belajar mengajar menganut pada sistem sekolah pada umumnya. Empat dari komponen-komponen yang ada, diantaranya adalah tujuan, isi kurikulum, strategi dan evaluasi. Spesifikasi Komponen tujuan berkaitan dengan empat kompetensi inti lulusan yang harus dikuasai atau dicapai oleh santri PPMI Assalaam yaitu kompetensi inti spiritual, intelektual, moral, dan keterampilan. komponen Isi kurikulum PPMI Assalam Surakarta diselenggarakan dalam tiga bentuk kegiatan yaitu kegiatan kurikuler, kegiatan ko-kurikuler dan kegiatan ekstrakulikuler. Komponen strategi pembelajaran yang digunakan untuk mengaktifkan peserta didik agar berpartisipasi aktif dalam pembelajaran secara demokratis dan menyenangkan. Komponen evaluasi berisi penilaian yang dilakukan secara terus menerus dan bersifat menyeluruh.
\end{abstract}

Kata Kunci: pengembangan kurikulum, pondok pesantren modern Islam Assalam Surakarta 


\section{PENDAHULUAN}

Pondok pesantren adalah sebuah lembaga konvensional yang secara literal bermakna sebagai suatu lembaga yang ditinggali oleh santri untuk memperoleh ilmunya (Depag, 2003). Sebagai lembaga pendidikan, pondok pesantren telah membuktikan diri memiliki peran penting dalam meningkatkan pengetahuan masyarakat, terutama pendidikan yang berkaitan dengan ilmu-ilmu keagamaan. Eksistensi pondok pesantren harus selalu dikembangkan agar secara kontinuitas mencetak para insan muslim yang berakhlak mulia, bertaqwa, dan rasa tanggung jawab yang tinggi dalam melakukan suatu hal untuk kemaslahatan kemajuan bangsa dan negara Indonesia.

Pada era modern ini, pondok pesantren dituntut harus memiliki suatu kurikulum yang dapat secara efektif dan efisien mengintegrasikan dua hal utama yang dianggap penting, yaitu ilmu keagamaan dan ilmu pengetahuan dan teknologi (IPTEK) yang ada dalam skema memaksimalkan kapabilitas keterampilan, pengetahuan, dan sikap. Kaitannya dalam menyusunan dan mengembangkan kurikulum harus selalu disinkronkan dengan kemajuan perkembangan ilmu pengetahuan dan zaman terkini. Pengembangan kurikulum juga termasuk dalam proses meraih visi dan misi, sehingga diharapkan mampu menghasilkan lebih optimum. Menjawab tantangan perubahan zaman yang ada, pondok pesantren telah menyiapkan para santri dengan berbagai keterampilan sesuai dengan permintaan pangsa kerja terhadap sumber daya manusia yang berkualitas untuk ikut andil dalam pembangunan masyarakat demi kesejahteraan sosial dan mampu beradaptasi dalam menghadapi perubahan. Berdasarkan misi tersebut, Pondok Pesantran Modern Islam (PPMI) Assalam Surakarta berupaya untuk selalu memperbaiki diri, salah satunya dengan pengembangan kurikulum pada beragam aspek.

Kurikulum merupakan suatu cara yang digunakan untuk mempersiapkan peserta didik untuk mampu berpartisipasi dengan baik sebagai angggota yang berproduktif dalam masyarakat (Nasution, 2003). Kurikulum juga dapat dilihat sebagai sebuah instrumen pendidikan yang mengantarkan seorang indivdu sehingga menguasai kompetensi pengetahuan, keterampilan, dan sikap agar menjadi individu dan warga negara yang kreatif, kreatif, inovatif, produktif, serta afektif (Kemendikbud, 2013). Kurikulum disusun untuk memudahkan dalam kegiatan belajar mengajar yang berada dalam naungan tanggung jawab dari suatu lembaga pendidikan dengan tenaga kependidikannya. Komponen kurikulum sendiri mencakup beberapa hal seperti tujuan sekolah, materi yang akan digunakan, metode yang diterapkan, pengorganisasian, dan evaluasi (Hamalik, 2007).

Kurikulum yang baik harus selalu dikembangkan sesuai dengan kebutuhan. Untuk itu, perlu dilakukan pengembangan kurikulum di suatu lembaga pendidikan untuk terus meningkatkan mutu pendidikannya. Pengembangan kurikulum merupakan proses menyusun suatu kurikulum, baik penyusunan kurikulum baru maupun penyempurnaan kurikulum yang telah ada. Pengembangan kurikulum dilakukan dengan menyusun perangkatperangkatnya yang dimulai dari hal yang mendasar hingga arahan pelaksanaannya (Sukmadinata, 2013). Pengembangan 
terhadap kurikulum dilakukan melalui pemaduan berbagai komponen yang pada akhirnya menciptakan sebuah kurikulum yang dianggap lebih baik, atau dapat dikatakan kegiatan untuk menyusun sebuah implementasi dan evaluasinya sehingga kurikulum disempurnakan (Zaini, 2009). Guna meningkatkan mutu pendidikan nasional, pengembangan terhadap kurikulum harus dilaksanakan secara cermat dan komprehensif dan lebih menekankan mutu pendidikan yang berkaitan dengan apa yang dibutuhkan masyarakat umum.

Pengembangan kurikulum yang dilaksanakan oleh PPMI Assalam adalah bentuk tanggapan terhadap permintaan masyarakat mengenai keadaan lingkungannya. Melalui pengembangan kurikulum yang dilakukan pendidikan pesantren, maka pendidikan dengan sistem tersebut dapat menjadi opsi bagi masyarakat untuk tempat belajar bagi anak-anaknya dalam memperoleh ilmu pengetahuan dengan pengukuhan keimanan dan akhlak mulia yang menjadi identitas pesantren. Hal tersebut selaras dengan visi yang diharapkan PPMI Assalam yaitu terbentuknya seseorang yang memiliki keharmonisan baik secara sisi spiritual maupun sisi intelektual, serta moral baik untuk diarahkan menjadi generasi Ulul Albab yang tinggi komitmen akan kemaslahatan umat yang berlandaskan pengabdian kepada Allah SWT.

Berdasarkan pernyataan Pusat Kurikulum Depdiknas yang menyatakan bahwa kurikulum memungkinkan untuk dikembangkan dengan menitikberatkan variasi karakteristik yang ada pada peserta didik, tingkatan dan tipe pendidikan, keadaan daerah serta toleransi tinggi terhadap keberagaman sosial yang ada di masyarakat. Kurikulum mencakup intisari dari komponen yang terdiri dari muatan pokok kurikulum, muatan lokal, dan proses mengembangkan peserta didik yang sistematis, kemudian diatur dalam kaitannya dan kontinuitas yang memiliki makna dan sesuai antar intisari tersebut (Aly, 2012). Ditinjau dari kompleksitasnya yang tinggi di pondok pesantren, maka proses mengembankan kurikulum harus menempuh strategi yang selaras dengan identitas pesantren sebagai lembaga pendidikan yang pertama kali berdiri di Indonesia dengan nafas islami. Pondok pesantren diwajibkan mampu meningkatkan fleksibilitasnya untuk merubah diri ke dalam berbagai format yang releban dengan apa yang dibutuhkan masyarakat saat ini, serta mampu menghasilkan keluaran berupa santri yang memiliki kualitas unggul sehingga tingkat penerimaan dari masyarakat menjadi tinggi. Oleh karena itu, pondok pesantrern harus mengaplikasikan suatu strategi dalam pengembangan kurikulum yang bertujuan untuk menciptakan kurikulum yang dianggap lebih baik. Akdon (2009) menjelaskan bahwa strategi merupakan rencana yang digabungkan, komprehensif dan sistematis yang kemudian mengombinasikan antara keunggulan atas strategi organisasi yang dimiliki dengan tantangan lingkungan yang ada dan dipastikan perancangangannya memiliki tujuan utama dari organisasi yang harus dicapai dengan realisasi yang tepat. Srategi yang digunakan dalam manajemen organisasi sendiri adalah sebuah kebijakan dan upaya yang dilaksanakan untuk pengembangan proses terefektif untuk meraih tujuan yang telah ditentukan (Glueck \& Jauch, 2000). 
Berdasarkan paparan-paparan yang telah dijelaskan di atas mengenai pentingnya pengembangan kurikulum yang terdapat pada pondok pesantren, maka strategi yang ditempuh sebuah pondok pesantren dalam pengembangan kurikulumnya sangat krusial. Melalui pengembangan kurikulum dan strateginya, pondok pesantren berupaya menciptakan mutu pendidikan yang tinggi sesuai visi dan misinya dan releven dengan tuntutan perkembangan zaman. Oleh karenta itu, peneliti akan mengkaji mengenai bagaimanakah pengembangan kurikulum di PPMI Assalam Surakarta.

\section{METODE PENELITIAN}

Penelitian ini ialah penelitian yang menggunakan metode deskriptif kualitatif sebagai metode penelitiannya. Pendekatan penelitian yang digunakan adalah pendekatan studi kasus, melalui pendekatan tersebut, peneliti berusaha memahami dan menganalisis pengembangan kurikulum yang terjadi di pondok pesantren. Penelitian ini memfokuskan pada pengembangan kurikulum yang terdapat pada PPMI Assalam Surakarta. Data penelitian ini berupa strategi yang berkaitan dengan belajar mengajar di PPMI Assalam Surakarta yang menunjukkan pengembangan kurikulum. Penelitian ini menggunakan sumber data yang berupa dokumen atau literatur yang berkaitan dengan pengembangan kurikulum di pondok pesantren. Proses mengumpulkan data penelitian menggunakan teknik wawancara mendalam dari informan. Dalam melakukan analisis data penelitian, peneliti menggunakan teknik analisis data model interaktif. Miles, Huberman, \& Saldana (2014) menjelaskan bahwa dalam model interaktif peneliti melakukan kegiatan secara bersamaan, yaitu: pertama reduksi data (data reduction); kedua penyajian dta (display data); dan terakhir penarikan kesimpulan atau verifikasi.

\section{HASIL DAN PEMBAHASAN}

Tiga kurikulum yang masuk dan dijadikan sebagai pedoman kurikulum PPMI Assalam diantaranya adalah memadukan kurikulum Kemendikbud, kurikulum Kemenag, dan Kurikulum muatan lokal termasuk muatan lokal berbasis pondok pesantren. Dalam menjawab kebutuhan pembangunan nasional dan tantangan global, pendidikan yang terdapat dalam Pendidikan PPMI Assalaam berusaha mengintegrasikan antara ilmu agama dan ilmu umum. Perencanaan penerapan pola pendidikan PPMI Assalam dirancang secara Adapun penerapan pola pendidikan PPMI Assalaam dirancang secara komprehensif atau bersifat mampu menerima keterpaduan antara dua sistem manhaj pendidikan. Diantaranya adalah pola pendidikan salafiyah yang lebih pada sistem tradiosional serta sistem modern yang kerap kali disebut dengan istilah Majmaul Bahraini. Perpaduan tersebut dalam kegiatan pembelajaran berporos pada sistem sekolah seperti umumnya. Kemudian manajemen kehidupan santri dalam sehari-hari dijalankan dan diatur dalam sistem asrama, sebagaimana pesantren salafiyah lainnya yakni menggunakan sistem tata tertib dan disiplin dalam pondok. Kurikulum yang dirancang dan dikembangkan, diharapkan nantinya mampu mewujudkan para santri agar memiliki ilmu pengetahuan yang luas baik ilmu Islam maupun dinul Islam, baik dalam berakidah shalihah yang 
mantap, serta mampu mengikuti perkembangan teknologi yang ditunjang dengan akhlakul karimah. PPMI Assalam mengembangkan kurikulum berdasarkan dari sistem pendidikan tersebut. Selain itu, sistem pendidikan yang digunakan mencakup empat komponen sebagai unsur pengembang kurikulum. Empat komponen tersebut berupa: tujuan, isi kurikulum, strategi dan evaluasi.

1. Tujuan

Beberapa tingkatan terbagi dalam komponen tujuan diantaranya adalah tujuan pendidikan nasional, tujuan institusional, tujuan kurikuler dan tujuan instruksional. Perumusan Visi dan Misi, SKL, dan KD pada setiap mata pelajaran yang akan diajarkan mulai ditetapkan sebagai tujuan. Bahan pelajaran yang diajarkan dan pengalaman yang diberikan kepada santri dirancang sebagai isi kurikulum untuk mendukung kualitas siswa. Adapun dalam proses pemilihan isi, dipilih dan disesuaikan berdasarkan dengan visi, misi, dan tujuan yang telah dirancang. Pembuatan isi kurikulum akan dimulai dengan mengonsep pembuatan struktur program, kemudian selanjutnya ditetapkan untuk pembuatan silabus pada masing-masing mata pelajaran. Penyusunan silabus pada masing-masing pelajaran disesuaikan dengan SK dan KD yang telah dirumuskan sesuai dengan waktu yang telah dialokasikan.

Pada uraian selanjutnya, pengembangan kurikulum PPMI Assaalam akan ditinjau ulang yang berkaitan dengan beberapa substansi untuk diberikan rumusan. Ciri khas dan tuntutan kurikulum PPMI Assaalam akan mengadaptasi rumusan standar
Kompetensi lulusan. Misalnya keterampilan dan pengetahuan yang tertera pada rumusan standar kompetensi lulusan kurikulum 2013 kemendikbud dapat diubah dan disesuaikan dengan rumusan kompetensi yang ada di pondok, seperti kompetensi spiritual, intelektual, moral keterampilan, dan dimensi Kompetensi Sikap. Sesuai dengan rumusan visi Assalaam yang meliputi spiritual, intelektual, moral dan keterampilan, maka ada empat kompetensi inti lulusan yang harus dikuasai atau dicapai oleh santri PPMI Assalaam, yaitu: (1) Kompetensi Inti Spiritual, (2) Kompetensi Inti Intelektual, (3) Kompetensi Inti Moral, dan (4) Kompetensi Inti Keterampilan.Masingmasing Kompetensi Inti dijabarkan ke dalam profil lulusan dan indicator dari profil lulusan

2. Isi

Ketercapaian berupa perencanaan persiapan isi kurikulum yang berupa bahan ajar diharapkan sesuai dengan tujuan dan dapat tercapai secara maksimal. Isi kurikulum yang beragam bergantung pada pada keluasan dan kedalaman tujuan yang direncanakan. Keefektifan dan keefisienan bahan ajar pada saat diajarkan pada santri dapat diorganisir secara tepat dan cerdas. Berdasarkan penjabaran isi tersebut, kegiatan kurikuler, ko-kurikuler, dan kegiatan ekstrakurikuler diselenggarakan sebagai isi kurikulum yang ada di PPMI Assalam. Tiga bentuk kegoatan tersebut pada masingmasing bentuk akan dijelaskan di bawah ini.

a. Aspek kognitif ditekankan pada kegiatan kurikuler, sebab melalui 
model kurikulum akan diselenggarakan persekolahan. Pada aspek ko-kurikuler afektif diselenggarakan melalui model dalam bentuk pengalaman hidup. Kemudian ekstra kurikuler pada psikomotorik penyelenggaraan melalui model keterampilan. Definisi dari kegiatan kurikuler pondok merupakan suatu kegiatan pendidikan yang memuat sembilan mata pelajaran yang dimasukkan ke dalam struktur kurikulum sekolah. Adapun kesembilan mata pelajaran tersebut ialah: (1) al-Lugah alInjliziyah, (2) al-Lugah al'Arabiyah (3) Aqidah,(4) Akhlaq (5) Tahfidz (6) Fiqih (7) Thariqah at Ta'lim, (8) Tarikh al-Islam atau Tsaqafah Islamiyah, dan (9) Qira'atul Quran. Kesembilan mata pelajaran tersebut merupakan struktur mata pelajaran yang melekat pada kurikulum sekolah. Waktu penyelenggaraan kesembilan mata pelajaran tersebut mulai pagi pada pukul 07.00 - 12.40 WIB. Kegiatan kurikuler tersebut merupakan kegiatan wajib yang harus diikuti oleh seluruh santri PPMI Assalam.

b. Kedua merupakan kegiatan kokurikuler. Kegiatan ko-kurikuler pondok tersebut dimaksudkan sebagai suatu kegiatan pendidikan yang mendukung kegiatan kurikuler. Adapun waktu pelaksanaan kegiatan ini, diselenggarakan pada waktu pagi dan malam hari. Seperti halnya kegiatan kurikuler, kegiatan kokurikuler terdapat enam mata pelajaran, diantaranya adalah: (1) Qira'atul Quran,
AlMuhadharah (3) Tazwid wa Tasyji' al-Lughah,(4) AlMuhadatsah,(5) Dirosah atTafsir (6) Qiro 'ah al-Kitab.

c. Ketiga adalah kegiatan ekstra kurikuler. Kegiatan ekstrakurikuler dimaknai sebagai kegiatan pendidikan yang berusaha mengembangkan minat dan bakat siswa baik dalam bidang olahraga, kesenian, maupun keterampilan yang dimiliki para santri. Waktu kegiatan dilaksanakan pada sore hari dan jumat pagi. Pemilihan kegiatan ekstrakurikuler dapat dipilih secara bebas sesuai potensi, minat dan bakat serta kecenderungan yang disukai oleh para santri. Selain itu, kegiatan ekstrakurikuler dalam setiap bidang minat dan bakat disediakan fasilitas oleh ustaz, guru dan pelatih. Fasilitas lain yang diberikan selain guru, ustaz dan pelatih adalah menyediakan fasilitas yang mendukung kegiatan seperti tempat dan berbagai jenis peralatan. Seperti kegiatan bidang olah raga, tempat kegiatan dipusatkan di lapangan, GOR dan tempat-tempat terbuka lainnya. kemudian, bidang keterampilan dan kesenian menempati ruang keterampilan dan ruang kelas yang ditunjuk.

3. Komponen strategi pembelajara dapat dilihat melalui cara yang tersedia dalam melaksanakan kegiatan pengajaran. Dalam cara mengadakan penilaian, melaksanakan bimbingan dan mengadakan penyuluhan serta mengatur kegiatan sekolah secara keseluruhan. Pelaksanaan pengajaran dilakukan dengan cara mencakup yang berlaku dalam menyajikan tiap bidang studi. 
Dalam hal ini termasuk bagaimana cara mengajar dengan alat pelajaran yang digunakan sebagai pendukung pengajaran maupun pembelajaran. Model implementasi kurikulum pesantren yang bersifat multikultural menghendaki guru menggunakan strategi pembelajaran yang dapat mengaktifkan peserta didik agar berpartisipasi secara aktif dan demokratis serta menyenangkan (SNP, Bab IV, Pasal 19, Ayat 1, 2005), hal tersebut sebagai salah satu aspek strategi pembelajaran. Menciptakan suasanan kelas yang hidup, nyaman dan menyenangkan. Hubungannya dengan ini, terdapat beberapa alternatif strategi pembelajaran yang ditawarkan. Diantaranya, (a) ceramah interaktif, (b) pembelajaran aktif, (c) pembelajaran kolaboratif, (d) diskusi kelompok, (e) bermain peran, dan (f) keteladanan. Strategi-strategi pembelajaran yang disebutkan di atas, dapat disiasati oleh para guru dalam menciptakan kelas yang hidup dan menjadikan siswa aktif dalam kelas. Adapun strategi alternatif yang berjumlah enam tersebut ditawarkan dengan alasan karena keenam strategi pembelajaran tersebut relavan untuk menyampaikan materi ajar yang sarat dengan nilai, seperti nilai keragaman, nilai perdamaian, nilai demokrasi, dan nilai keadilan.

4. Evaluasi Komponen

Selanjutnya evaluasi komponen adalah wujud penilaian yang berisi cara untuk melakukan evaluasi secara kontinu dan bersifat menyeluruh. Evaluasi secara terus menerus tersebut dilakukan untuk menilai bahan ajar atau program pengajaran yang dituju. Hal tersebut sebagai uapaya memberikan respon pada tujuan, materi, metode, sarana, dalam rangka membina dan mengembangkan kurikulum lebih lanjut agar lebih baik dan maksimal. Evaluasi dapat dilakukan dengan pelaksanaan teknik-teknik secara bertahap dan berkelanjutan. Evaluasi harian, evaluasi blok, evaluasi tengah semester, dan evaluasi akhir semester ditandai dengan evaluasi yang bertahap dan berkelanjutan. Sesuai dengan ketetapan dan ketentuan evaluasi yang distandarkan oleh Badan Standar Nasional Pendidikan (BSNP, Bab X, Pasal 64, Ayat 1, 2005) model evaluasi hasil pembelajaran ini dipilih sebagai alasan karena model evaluasi ini memiliki kesamaan dan keterikatan dengan model evaluasi yang dirancang oleh BSNP tersebut.

Model evaluasi jenis ini memungkinkan terjadinya evaluasi yang fair dan adil. Untuk memutuskan kelulusan peserta didik, tidak hanya ditentukan oleh hasil evaluasi tengah dan akhir semester, melainkan juga ditentukan oleh evaluasi harian dan evaluasi blok. Oleh sebab itu, diperlukan evaluasi yang fair dan adil. Beberapa nilai yang termuat dalam materi-materi ajar diantaranya terdapat empat nilai salah satunya adalah nilai demokrasi, nilai keadilan, nilai keragaman, dan nilai perdamaian. Sesuai dengan Undang-undang yang tertulis pada Bab X, Pasal 64, Ayat 3 tahun 2005 yang distandarkan dengan evaluasi menurut BSNP menjadikan model evaluasi tersebut memberikan tuntutan pada guru untuk melakukan evaluasi berdasarkan pada tiga komponen tersebut. 
Adapun teknik hasil evaluasi yang ditawarkan dapat berupa tes lisan, tes tertulis, portofolio, kinerja, dan penugasan. Peserta didik yang dievaluasi haruslah adil dan seimbang, Oleh sebab itu pentingnya keragaman teknik evaluasi yang digunakan dapat menjadi solusi atas kemungkinan permasalahan-permasalahan yang muncul dalam diri peserta didik. Kegunaan masing-masing evaluasi yang ditawarkan diantaranya berupa tes lisan yang dapat digunakan untuk mengevaluasi domain kognitif, afektif, dan psikomotorik peserta didik. Kemudian tes tertulis beguna untuk memberikan evaluasi dalam domain kognitif peserta didik. Selanjutnya tes portofolio ialah tes yang berfungsi sebagai alat untuk mengeveluasi aspek kognitif dan afeektif peserta didik. Selain itu, terdapat pula tes unjuk kerja yang berguna untuk memberikan hasil evaluasi melalui aspek afektif dan psikomotorik peserta didik. Terakhir adalah tes penugasan yang berfungsi sebagai alat evaluasi tiga aspek yang dimiliki peserta didik. Dari keragaman model-model evaluasi tersebut, PPMI Assalam akan mendapatkan hasil atau keluaran yang bersifat seimbang dan adil dalam menentukan hasil dari peserta didik. Seimbang dan adil yang dimaksud disini adalah sesuai dengan keluaran apa adanya dan juga sesuai dengan kemampuan peserta didik.

\section{PENUTUP}

Hasil pembahasan di atas, memberikan simpulan bahwa model kegiatan belajar mengajar yang dianut PPMI Assalam terdiri dari dua sistem poal pendidikan. Yakni Salafiyah dan modern.
Namun secara pelaksanaan keduanya direalisasikan seperti sistem sekolah pada umumnya. Adapun dalam kegiatan seharihari, pelaksanaannya diatur oleh sistem asrama, sebagaimana pondok salafiyah pada umumnya. Menggunakan tata tertib, disiplin dan tanggung jawab. Berdasar pada pola pendidikan seperti itu, PPMI Assalam mengembangkan kurikulum melalui komponen-komponen kurikulum. Empat dari komponen-komponen yang ada, diantaranya adalah tujuan, isi kurikulum, strategi dan evaluasi. Spesifikasi dari masing-masing komponen yang pertama adalah komponen tujuan, komponen tujuan tersebut di dalamnya berkaitan dengan empat kompetensi. Adapaun keempat kompetensi tersebut berupa inti lulusan, kompetensi spiritualitas, kompetensi moral, dan keterampilan. Keempat kompetensi tersebut harus dikuasai oleh seluruh santri PPMI Assalam. Komponen kedua adalah komponne isi. Komponen isi di dalamnya diselenggarakan dalam tiga bentuk kegiatan, pertama kurikuler, ko-kurikuler, dan ekstrakurikuler. Kemudian yang ketiga, strategi pembelajaran yang digunakan adalah wujud upaya untuk menggerakkan peserta didik agar aktif dan tanggap dalam proses pembelaajaran yang berlangsung. Sebab, keaktifan siswa akan memberikan pengaruh besar bagi suasana kelas agar lebih hidup dan menyenangkan. Evaluasi selanjutnya adalah komponen terakhir. Komponen tersebut berisi penilaian yang bersifat terus menerus serta menyeluruh. Adapun evaluasi belajar yang disediakan berupa beragam tes, seperti tes lisan, portofolio, kinerja, penugasan, dan tes tulis.

\section{DAFTAR PUSTAKA}


Akdon. (2009). Strategic Manajement For Educational Manajement. Bandung: Alfabeta.

Aly, A. (2012). Model Kurikulum Pendidikan Islam Multikultural Di Pondok Pesantren Modern Islam Assalam Surakarta. Varia Pendidikan, 24(1).

Departemen Agama Republik Indonesia. (2003). Pola Pengembangan Pondok Pesantren. Jakarta: Direktorat Jendral Kelembagaan Agama Islam Kementrian Agama Republik Indonesia.

Glueck, W. F., \& Jauch, L. R. (2000). Business Policy and Strategic Management, and Integrated Approach. New York: Houghton Miflin Company.

Hamalik, O. (2007). Dasar-Dasar Pengembangan Kurikulum. Bandung: Remaja Rosdakarya.
Kemendikbud. (2013). Peraturan Menteri Pendidikan dan Kebudayaan Republik Indonesia Nomor 104 Tahun 2014 tentang Pedoman Penilaian Hasil Belajar. Jakarta: Kementerian Pendidikan dan Kebudayaan Republik Indonesia.

Miles, M. B., Huberman, A. M., \& Saldana, J. (2014). Qualitative Data Analysis: a Methods Sourcebook. Newbury Park: SAGE Publication Ltd. Retrieved from http://library1.nida.ac.th/termpaper6/s d/2554/19755.pdf

Nasution, S. (2003). Asas-Asas Kurikulum. Jakarta: Bumi Aksara.

Sukmadinata, N. S. (2013). Manajemen Kurikulum. Bandung: Alfabeta.

Zaini, M. (2009). Pengembangan Kurikulum (Konsep Implementasi dan Inovasi). Yogyakarta: Teras. 